
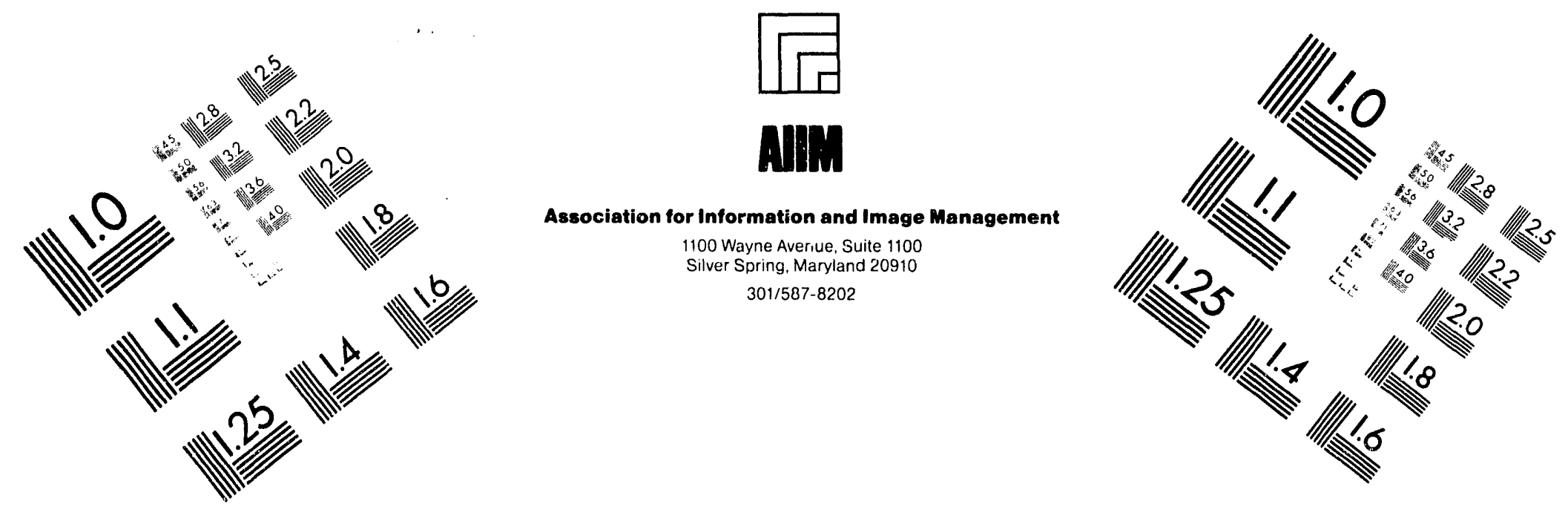

\title{
Centimeter
}

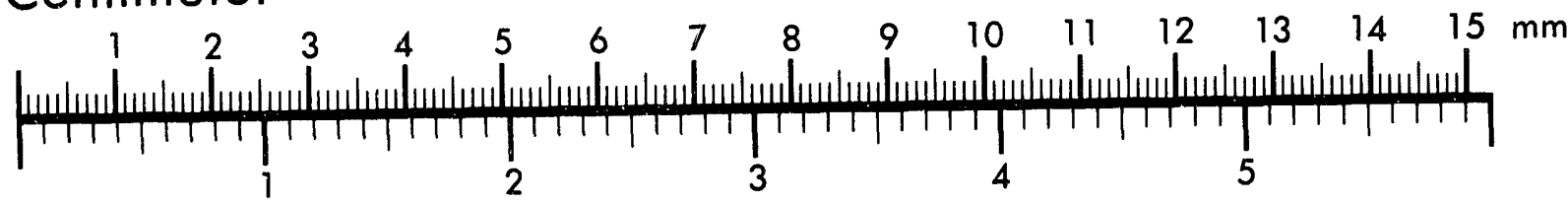
Inches
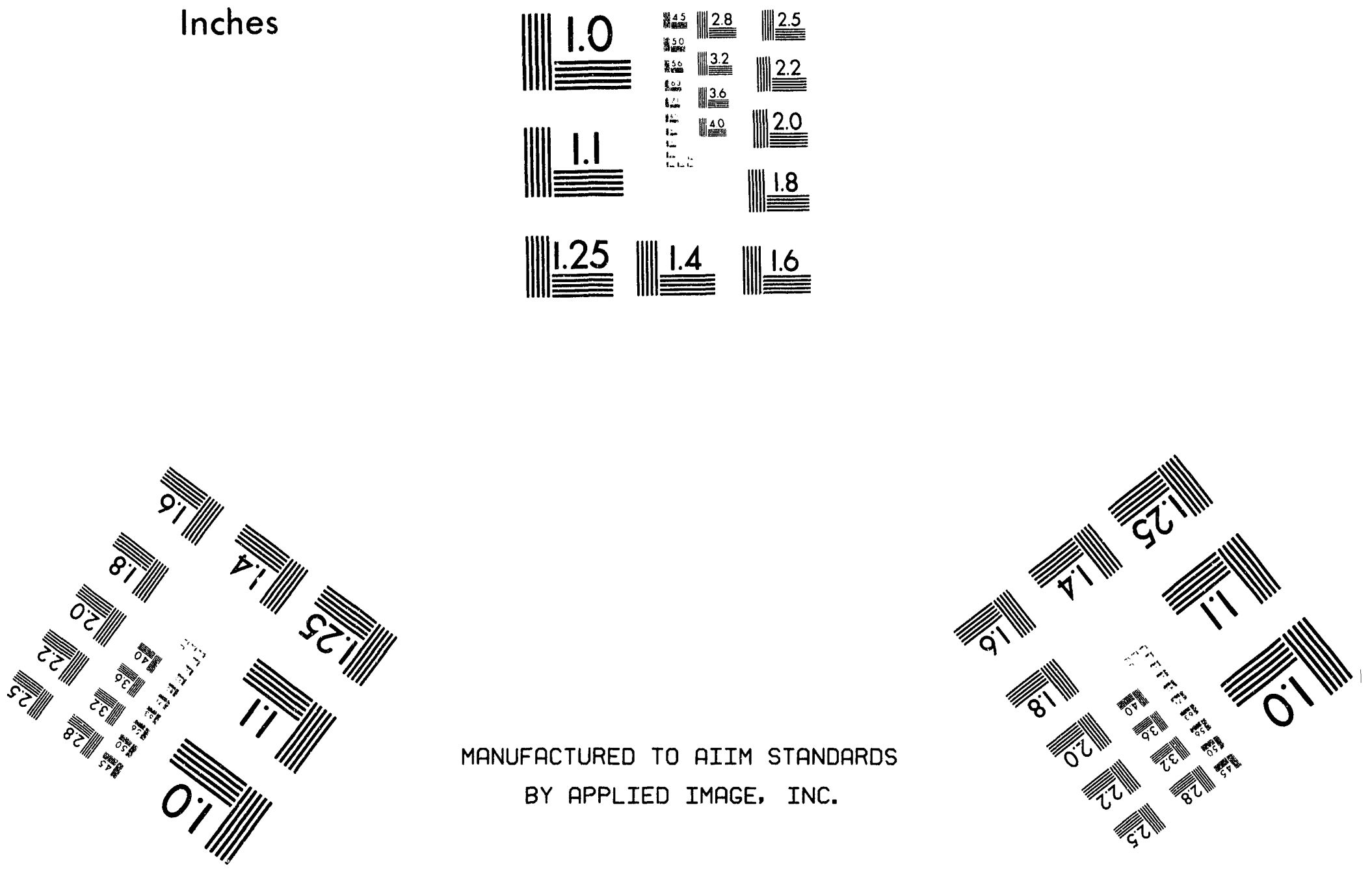

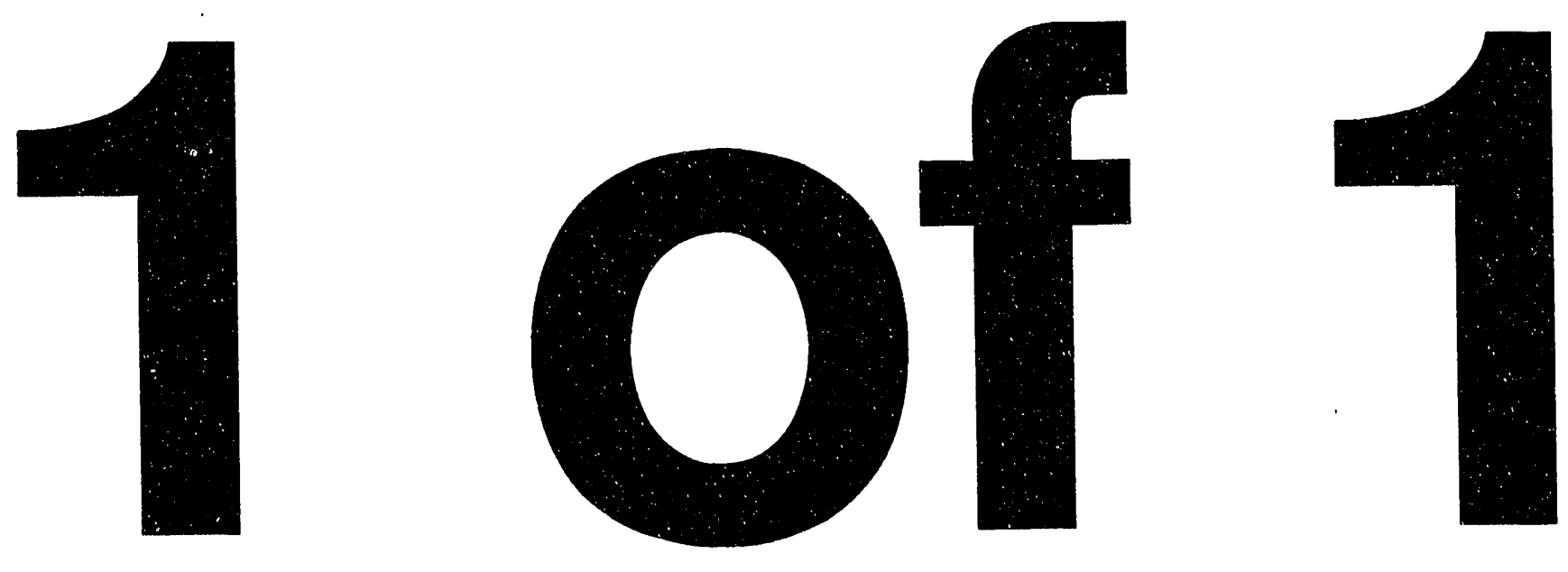


\section{ICPP WASTE MANAGEMENT TECHNOLOGY} DEVELOPMENT PROGRAM

G. W. Hogg, WINCO

A. L. Olson, WINCO

D. A. Knecht, WINCO

M. J. Bonkoski, U.S. DOE

January 1993

Westinghouse Idaho

PREPARED FOR THE

DEPARTMENT OF ENERGY

IDAHO OPERATIONS OFFICE

UNDER CONTRACT DE-AC07-84ID12435 


\section{INTRODUCTION}

Irradiated nuclear fuel has been reprocessed at the ICPP since 1953 to recover uranium-235 and krypton-85 for the U.S. Department of Energy. The resulting acidic radioactive waste has been converted to calcine since 1963 and stored in stainless steel bins enclosed in concrete vaults. Residual radioactive sodium-bearing waste is stored in stainless-steel underground tanks contained in concrete vaults. Several different types of unprocessed irradiated DOEowned fuels are also stored at INEL. In April, 1992, DOE announced that spent fuel would no longer be reprocessed to recover enriched uranium.

As a result of the decision to curtail reprocessing the Idaho Chemical Processing Plant (ICPP) Spent fuel and Waste Management Technology Development plan has been implemented to identify acceptable options for disposing of the (1) sodium-bearing liquid radioactive waste, (2) radioactive calcine, and (3) irradiated spent fuel stored at the Idaho National Engineering Laboratory (INEL). The plan was developed jointly by DOE and WINCO.

\section{DOE PERSPECTIVE OF PROGRAM}

The ICPP Waste Management Technology Development Program is a product of significant change throughout the world. Historically, the Department of Energy's strategy for the disposition of government-owned spent nuclear fuel has been to reprocess the fuel to recover highly enriched uranium (HEU). The resulting wastes would be solidified and placed in the geologic repository. With the advent of massive reductions in international nuclear weapons inventories, HEU supply greatly exceeds demand. This oversupply of HEU was the primary impetus leading to a decision by the Secretary of Energy in April of 1990 to phase out reprocessing of spent fuel to recover uranium, both at ICPP and the Savannah River site.

The removal of reprocessing as the basis for management of spent fuel and resulting high level waste has required a new approach to management of this material. The ICPP Spent Fuel and Waste Management Technology Development Program is one of the means to developing a new technical basis for high level waste management. 
Simply storing spent fuel and high level waste for an indefinite period is not a viable option. High level waste is subject to regulation under the Resource Conservation and Recovery Act (RCRA) and must be disposed of utilizing the Best Demonstrated Available Technology (BDAT). The BDAT for high level liquid waste has been established by the EPA to be vitrification. For ICPP high level waste which has been converted into a granular solid, the proposed BDAT is a glass-ceramic process. The Federal Facilities Compliance Act will require agreements with regulating state agencies to dispose of RCRA wastes on a negotiated compliance schedule. The indefinite storage of spent fuel, while technically feasible, is unlikely to receive public and state acceptance especially in Idaho. Also the question of spent fuel being subject to RCRA is under investigation.

Probably the most challenging part of the ICPP Technology Development Plan is the development of technologies for the dispositioning of spent fuel. The Nuclear Waste Policy Act of 1982 provides for the development of a geologic repository for the placement of commercial spent fuel and defense-generated, solidified, high level waste. The DOE is also required to assess the need for a second repository. The ICPP program will undertake development of repository acceptance criteria and dispositioning techniques to make currently stored fuels ready for storage at a repository. The ICPP has an inventory of numerous types of fuel both of commercial and defense origin. Changes in repository strategies or the possibility of introduction of a defense-related Monitored Retrieval Storage facility will require integration and coordination on a national basis to assure suitable technologies are developed.

The National Energy Strategy establishes a goal to establish an effective high level nuclear waste program. The ICPP Technology Development Program will be a positive contributor to accomplishment of that goal.

PROGRAM OBJECTIVES

The principal objectives of the ICPP Spent Fuel and Waste Management Technology Development Program are: 
1. Investigate direct disposal of spent fuel, striving for one waste form.

2. Determine the best treatment processes for liquid and calcine wastes to minimize HLW and LLW.

3. Demonstrate the integrated operability and maintainability of selected treatment and immobilization processes.

4. Assure that the final implementation is environmentally acceptable, ensures public and worker safety, and is economically feasible.

The strategy to obtain these objectives utilizes a system approach during development which will take into account all of the factors which may impact final disposition of waste and spent fuels and capitalize on all available technology both national and international (benchmark).

The ICPP technology development program resulting from the decision to curtail fuel reprocessing includes the following key elements:

1. Systems Analysis

2. Sodium Bearing Liquid Waste Processing

3. Calcine Immobilization

4. Spent Graphite Fuel Conditioning

5. Special Fuel Conditioning

6. Metal Recycle/Waste Minimization

\section{SYSTEMS ANALYSIS}

The objective of the Systems Analysis initiative is to develop a logical and consistent approach in executing the Spent Fuel and Waste Management Technology Development Program, looking at all aspects and developing the basis for integrated, strategic decision making using a structured systems method. Decisions will then be 
made based on regulatory compliance, reduced risk, reduced cost, increased safety, public acceptance, waste minimization, and other key issues. Systems Analysis will consist of two major thrusts: development of a preliminary repository performance assessment and an overall model for alternative comparison purposes.

A preliminary performance assessment, including an analytical model which will simulate confinement of waste forms in postulated repository situations, will be developed. Performance assessment is a method accepted to analyze engineered disposal systems for isolation of radioactive waste from humans and the environment. It provides a quantitative aspect to the analysis. The assessment will initially be based on general physical knowledge such as rock type and characteristics, water depth and movement, volcanic and seismic activity and the likelihood of migration of the stored waste out of the repository. Characteristics of the waste form, repository location, and repository design will be integrated into the analysis as they become available. The performance assessment will also identify any obvious short comings with the candidate waste forms, container design, and repository definitions. As appropriate, the waste forms, container design, or repository definitions which do not meet requirements will be revised or discarded.

Information gained from Systems Analysis will be used to focus the development efforts on the spent fuel and HLW conditioning and disposal processes that have the highest probability for success. As the development program progresses, the results of individual research programs will be incorporated into the performance assessment and system models. As results of the analyses and assessments become available, they will be reviewed and made accessible to the appropriate organizations in the development program. A flow diagram for Systems Analysis is given in Figure 1.

\section{TECHNOLOGY ACCEPTANCE CRITERIA}

Technology acceptance criteria are developed for all key program elements to guide development activities and assure a given task provides a necessary contribution to the total development program. Development of the acceptance criteria includes a schematic of options considered, a roadmap for reaching the endpoints and a 


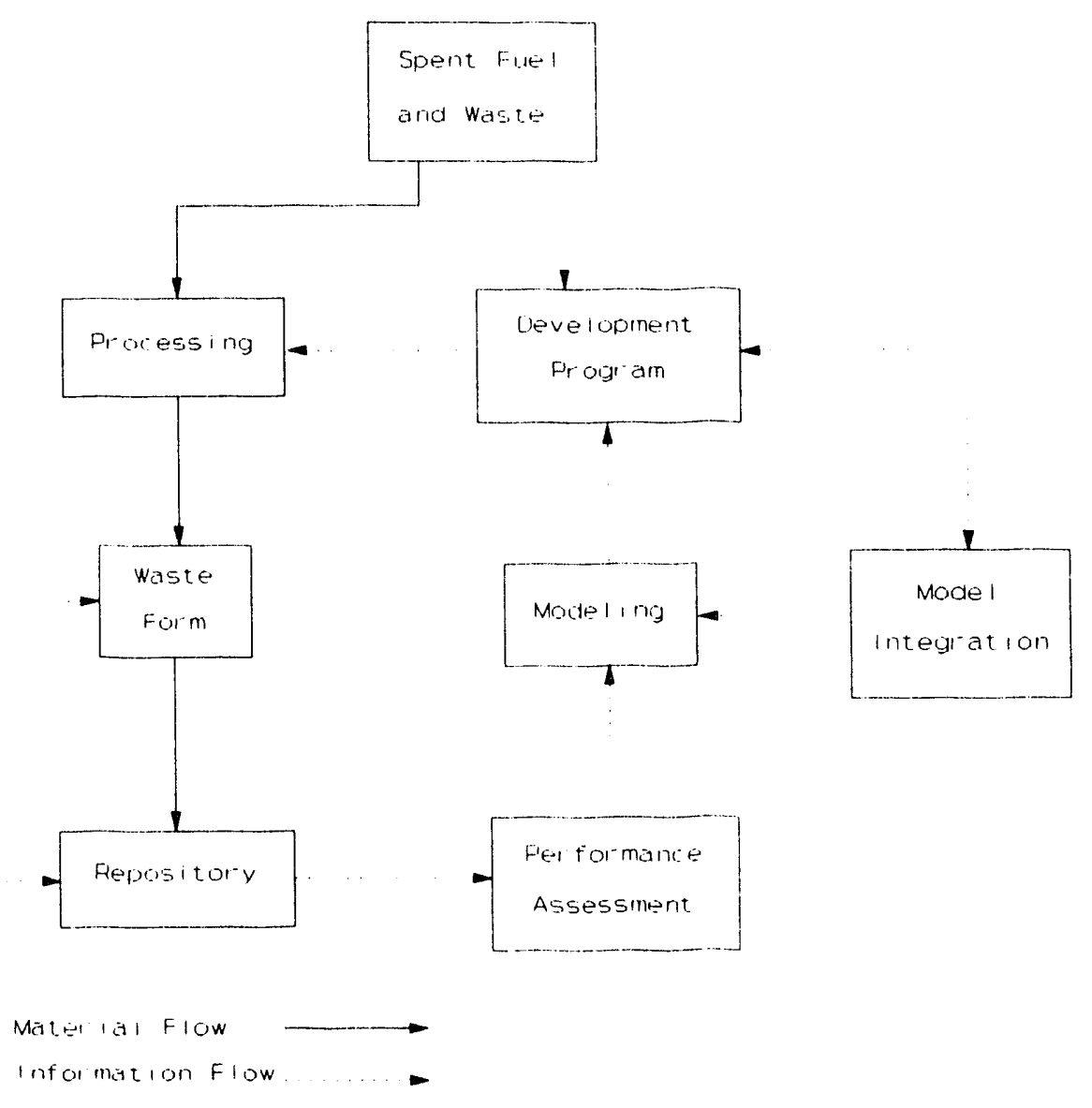

FIGURE 1 SYSTEMS ANALYSIS OVERVIEW

technology acceptance criteria matrix. The technology acceptance criteria matrix also serves as a check list to assure required development tasks are included in the development plan. A schematic diagram of how the acceptance criteria are used in the overall technology selection process is given in Figure 2 and a representative matrix is shown in Table $I$.

Before a detailed evaluation can be made, a preliminary screening is carried out to narrow potential candidates to a reasonable number. This screening process consists of first generating a group of required or absolute criteria. All potential technological options are subject to these criteria. 


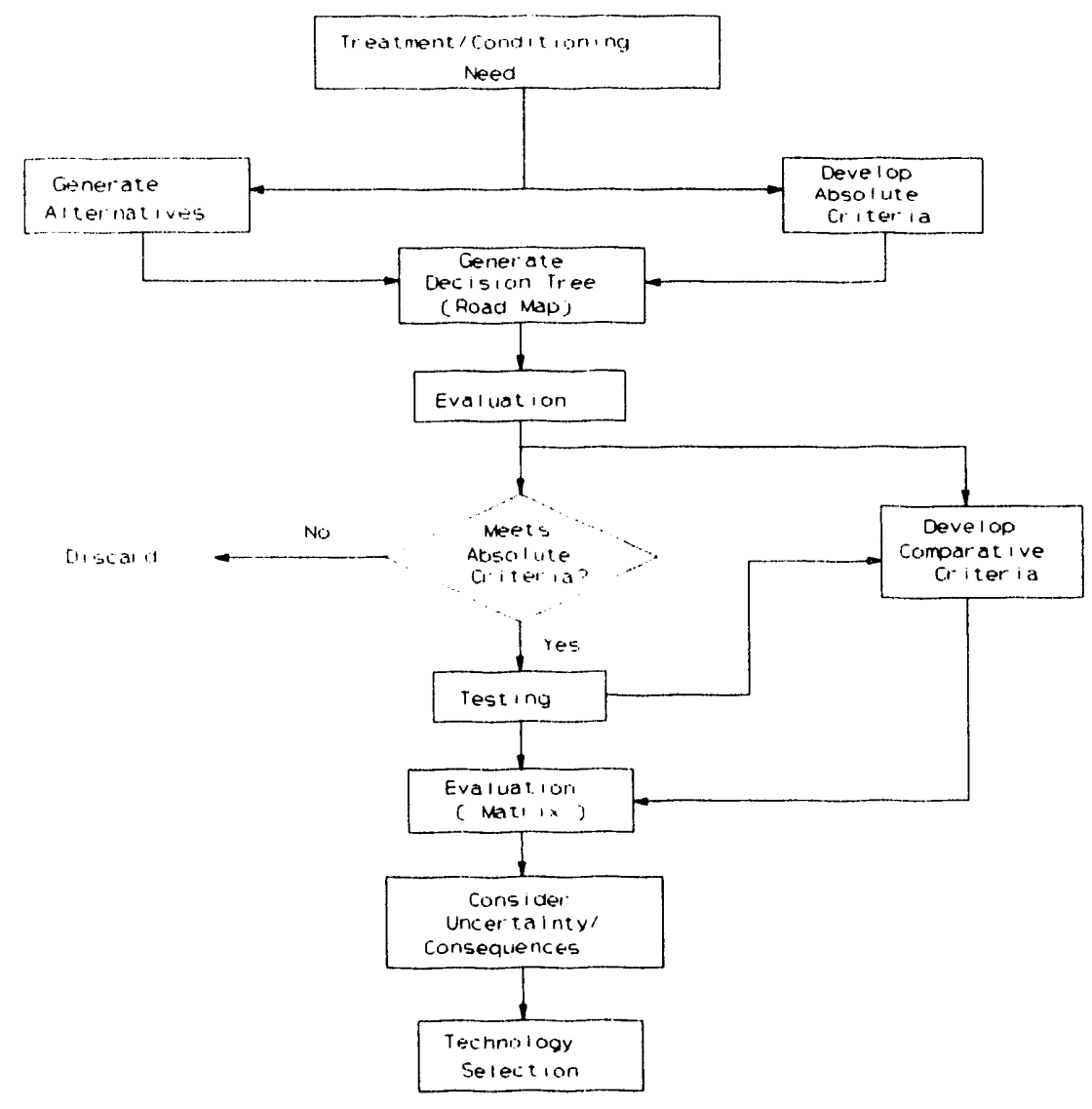

Figure 2 TECHNOLOGY ACCEPTANCE PROCESS

When several candidate alternatives meet the absolute criteria and a decision on a particular option is needed a detailed evaluation is made. A set of criteria are established and weighted according to its perceived importance. Each alternative is then ranked as to how well it measures up to the individual criteria. Thus, the process provides a structured, quantitative method of evaluating technologies to be developed.

\section{SPENT FUEL CONDITIONING}

The DOE currently has approximately 768 metric tons (MT) total mass of material labeled as "special fuel" stored at the INEL. This 
Table I

EXAMPLE CRITERIA EVALUATION MATRIX

\begin{tabular}{|c|c|c|c|c|}
\hline Criteria & $\begin{array}{l}\text { Weighting } \\
\text { factor } \\
\text { (WF) } \\
\end{array}$ & $\begin{array}{c}\text { Alteruative } 1 \\
\text { Rating X WF }=\text { Score }\end{array}$ & $\begin{array}{c}\text { Alternative } 2 \\
\text { Rating X WF }=\text { Score }\end{array}$ & $\begin{array}{c}\text { Alteruative } 3 \\
\text { Rating X WF }=\text { Score }\end{array}$ \\
\hline $\begin{array}{l}\text { Technical } \\
\text { Performance }\end{array}$ & WFI & $\mathrm{WF} 1 \times \mathrm{R} 1$ & $W F 1 \times R 2$ & WF1 X R3 \\
\hline $\begin{array}{l}\text { Waste } \\
\text { Considerations }\end{array}$ & WF2 & $W F 2 \times R I$ & WF2 X R2 & WF2 X R3 \\
\hline $\begin{array}{l}\text { Environinental, } \\
\text { Safety, \& Health }\end{array}$ & WF3 & WF3 X R1 & WF3 X R2 & WF3 X R3 \\
\hline Time Factors & WF4 & WF4 X RI & WF3 X R2 & WF4 X R3 \\
\hline Costs & WF5 & WF5 X RI & WF5 $\times$ R2 & WF5 X R3 \\
\hline Acceptance & WF6 & WF6 X RI & WF6 X R2 & WF6 X R3 \\
\hline D \& D Closure & WF7 & WF6 X RI & WF7 X R2 & WF6 X R3 \\
\hline Total (weighting) & 100 & - & - & - \\
\hline Total Score & & $\mathbf{A A A}$ & BBB & $\mathrm{CCC}$ \\
\hline
\end{tabular}

material is so labeled because no specific spent fuel processing technique or recycle facility is available within the DOE complex. There are over 90 identified types of special nuclear fuel at the INEL and over 100 types in the DOE complex. About 108 metric tons (MT) of graphite based fuels, 240 MT of Naval propulsion fuels, and 420 MT of various (zirconium, aluminum, and stainless steel based) fuels are stored at the INEL. The fuel characteristics are summarized in Table II. It is intended that this material be inspected, characterized, and technologies developed for interim 
TABLE II

SPENT FUEL CHARACTERISTICS

\begin{tabular}{llllll} 
oxide & SST & Al & Pu & high & H 40-50 \\
alloy & $\mathrm{Al}$ & $\mathrm{SST}$ & $\mathrm{C}$ & low & $\mathrm{M} 10-40$ \\
metal & $\mathrm{BeO}, \mathrm{MgO}$ & $\mathrm{Zr}$ & elc & deplete & $\mathrm{L} 1-10$ \\
hydride & $\mathrm{ZrO2, \textrm {CaO }}$ & none & & & neg $<1$ \\
& ThO2 & & & unkwn \\
& none & & & \\
\hline
\end{tabular}

\begin{tabular}{|c|c|c|c|c|c|}
\hline hydride & none & $\operatorname{mix}$ & C. Pu, Mo & H & L \\
\hline oxide & SST & SST & $\mathrm{Ti}, \mathrm{Pu}$ & $\mathbf{H}$ & $\mathbf{M}$ \\
\hline alloy & Al & $\mathrm{Al}$ & $\mathrm{Pu}$ & $\mathbf{H}$ & H \\
\hline oxide & $\mathrm{BeO}, \mathrm{MgO}$ & none & $\begin{array}{l}\mathrm{Be}, \mathrm{Mg}, \mathrm{Y} \\
\text { ceramic }\end{array}$ & $\mathbf{H}$ & $\mathbf{L}$ \\
\hline oxide & ZrO2 & $\mathrm{Zr}$ & $\mathrm{Pu}, \mathrm{B}$ & H & H \\
\hline oxide & $\mathrm{ZrO} 2, \mathrm{CaO}$ & $\mathrm{Zr}$ & $\begin{array}{l}\mathrm{ZrO} 2, \mathrm{CaO} \\
\text { eopxy }\end{array}$ & $\mathbf{H}$ & $\mathbf{H}$ \\
\hline alloy & $\begin{array}{l}\text { none } \\
\text { ThO2 }\end{array}$ & SST & $\begin{array}{l}\text { Th, Na, Mo } \\
\text { U-233 }\end{array}$ & L & U \\
\hline oxide & $\begin{array}{l}\mathrm{ThO} 2, \mathrm{CaO} \\
\mathrm{ZrO} 2\end{array}$ & $\mathrm{Zr}$ & $\begin{array}{l}\text { Th, } \mathrm{CaO}, \mathrm{Pu} \\
\mathrm{U}-233\end{array}$ & $\mathbf{L}$ & $\mathbf{U}$ \\
\hline alloy & none & $\mathrm{Zr}$ & $\mathrm{Na}$ mel, $\mathrm{Pu}$ & H & L \\
\hline oxide & SST & $\mathrm{Zr}$ & $\begin{array}{l}\text { B4C } \\
\text { thermal }\end{array}$ & $\mathbf{H}$ & $\mathbf{U}$ \\
\hline metal & none & SST & $\mathrm{Pu}, \mathrm{Na}$ & $\mathbf{H}$ & $\mathbf{H}$ \\
\hline metal & Mo & SST & $\mathbf{P u}$ & $L$ & $\mathbf{u}$ \\
\hline oxide & none & none & & $\mathbf{H}$ & neg \\
\hline oxide & none & $\mathrm{Zr}$ & $\mathrm{Be}, \mathrm{Pu}$ & $\mathbf{L}$ & $\mathbf{U}$ \\
\hline oxide & & $\mathrm{Zr}, \mathrm{SS}$ & $\mathrm{Pu}$ & $\mathbf{L}$ & $\mathrm{U}$ \\
\hline oxide & Nicrome & & & H & $U$ \\
\hline oxide & & & Pu & $\mathbf{L}$ & $\mathbf{U}$ \\
\hline oxide & & SST & $\mathrm{Pu}$ & L & $\mathbf{U}$ \\
\hline
\end{tabular}


storage, direct dispositioning, or processing. The dispositioring is especially complex because of the variety of fuel types.

The special fuel varies widely in characteristics. There are individual rods in buckets, fuel assemblies, canned fuel, fuel test assemblies, etc. The condition of fuel cladding also varies with some fuel intact and capable of continued storage as is and some fuel reduced to debris in buckets. Enrichments and burn-ups also vary widely.

The objective of the Spent Fuel Conditioning program is to characterize all the special fuel at the INEL and to develop technology for conditioning that spent fuel, striving for a single waste form, for dispositioning in a geologic repository. Fuel will be identified for subsequent inspection and characterization. Inspection issues will be evaluated and development of fuel inspection criteria will be developed. A high percentage of the fuel types have not been fully characterized. Characterization of each fuel type needs to be accomplished to determine handling and packaging methods and whether the fuel will be suitable for direct dispositioning or require conditioning.

Alternative conditioning methods will be investigated. The three major dispositioning options envisioned to date are shown in Figure 3. They consist of direct disposal, mechanical disassembly and encapsulation of the HLW, and chemical processing. Direct disposal of the fuel is the most simple alternative since it only involves handling, packaging and transport to a repository. However, criticality control is a major issue which must be resolved for this to be a viable alternative. Mechanical disassembly consists of removing bulk cladding materials for disposal in shallow land burial and encapsulation of the HLW material (fission products, actinides) for disposal in a repository. This alternative holds potential for significant minimization of the amount of HLW sent to a repository. Chemical processing would involve dissolution or burning of the fuel, perhaps separation of the HLW, and immobilization for disposal in a repository. This alternative holds the greatest potential for achieving a single waste form for dispositioning. A combination of these alternatives may be the most attractive disposal option as determined by the progression of development. 


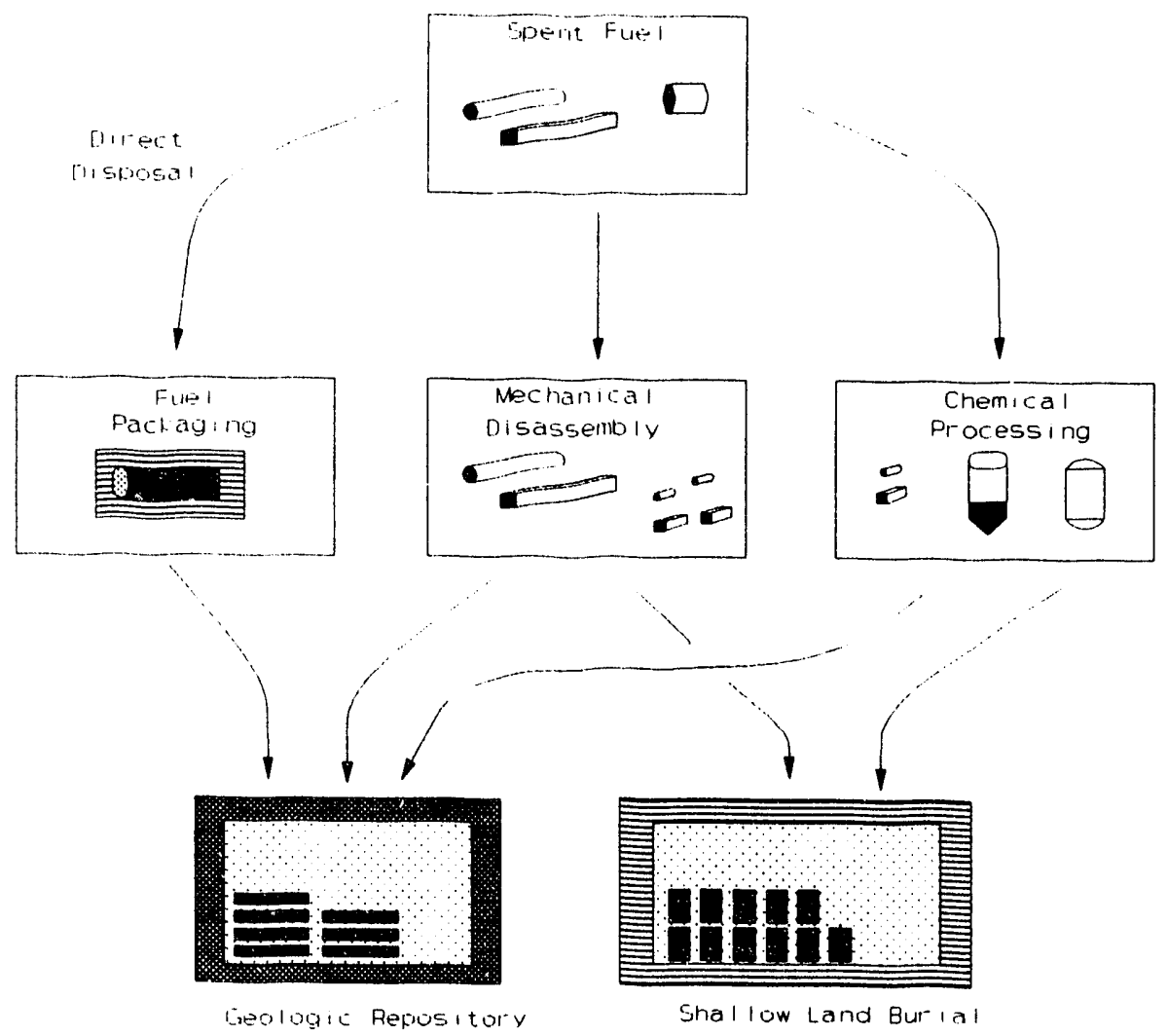

FIGURE 3 SPENT FUEL CONDITIONING OPTIONS

Laboratory and component testing of valid candidate processes will be performed to establish technology feasibility. Pilot plant and hot integrated testing of selected process(es) which meet health and safety, cost effectiveness and waste minimization criteria will be carried out to verify the process(es) prior to a full scale facility being placed in operation.

SODIUM-BEARING LIQUID WASTE TECHNOLOGY

Process operations and decontamination activities at the ICPP have resulted in the accumulation of approximately 1.5 million gallons of radioactively contaminated, liquid waste. The chemical 
composition of these sodium-bearing wastes are given in Table III. Tr.e waste is currently stored in stainless steel tanks which are

TABLE III

CHEMICAL COMPOSITION OF SODIUM-BEARING WASTE

\begin{tabular}{|c|c|c|}
\hline $\begin{array}{l}\text { Component } \\
\text { (moles/liter) }\end{array}$ & $\begin{array}{l}\text { Avg. Composition } \\
\text { (moles/liter) }\end{array}$ & Range \\
\hline Acid $\left(\mathrm{H}^{+}\right)$ & 1.45 & $0.43-1.92$ \\
\hline Nitrate $\left(\mathrm{NO}_{3}\right)$ & 4.36 & $2.93-5.79$ \\
\hline Aluminum $\left(\mathrm{A}^{3++}\right)$ & 0.55 & $0.21-0.81$ \\
\hline Sodium $\left(\mathrm{Na}^{*}\right)$ & 1.26 & $0.78-2.00$ \\
\hline Potassium ( $\left.\mathbf{K}^{*}\right)$ & 0.15 & $0.10-0.23$ \\
\hline Fluoride $(\mathbf{F})$ & 0.07 & $0.04-0.17$ \\
\hline Zirconium $\left(\mathrm{Zn}^{\mathrm{N}^{+}}\right)$ & 0.003 & $0,000-0000$ \\
\hline Boron $\left(B^{3+}\right)$ & 0.018 & $0.007 \cdot 0.0024$ \\
\hline Calcium $\left(\mathrm{Ca}^{2+}\right)$ & 0.04 & $0.00-0.07$ \\
\hline Chloride (Cl) & 0.02 & $0.008-0.043$ \\
\hline Iron $\left(\mathrm{Fe}^{2+, 4+}\right)$ & 0.03 & $0.01-0.05$ \\
\hline Chromium $\left(\mathrm{Cr}^{2+, 3+, 6 *}\right)$ & 0.006 & $0.002-0.013$ \\
\hline Cadrnium $\left(\mathrm{Cd}^{2+}\right)$ & 0.002 & $0.000-0.004$ \\
\hline Lead $\left(\mathrm{Pb}^{2+.4+}\right)$ & 0.001 & $0.001-0.002$ \\
\hline Mercury $\left(\mathrm{Hg}^{1+, 2+}\right)$ & 0.002 & $0.001-0.008$ \\
\hline Manganese $\left(\mathrm{Mn}^{2+.3+.4+.7+}\right)$ & 0.01 & $0.01-0.02$ \\
\hline Phosphate $\left(\mathrm{PO}_{4}^{3}\right)$ & 0.009 & $0.00-0.03$ \\
\hline Sulfate $\left(\mathrm{SO}_{4}{ }^{2 \cdot}\right)$ & 0.04 & $0.01-0.07$ \\
\hline Specific Gravity & 1.22 & $1.15-1.26$ \\
\hline
\end{tabular}

contained in underground concrete vaults. These tanks do not meet either new seismic codes or RCRA requirements for secondary containment. A Cinsent Order to the State of Idaho's Notice of 
Noncompliance requires that the waste be depleted from all of the tanks by 2015 .

The previous method for disposing of sodium-bearing waste was to calcine it with a blend of radioactive waste from spent fuel reprocessing to dilute the sodium concentration. Sodium-bearing waste cannot be calcined by itself due to the low melting points of sodium and potassium salts relative to the calcination temperature $\left(500^{\circ} \mathrm{C}\right)$. However, with the recent decision to curtail fuel reprocessing, this waste will no longer be available for blending with the sodium-bearing waste. It is also possible to calcine this material via the addition of nonradioactive aluminum nitrate, but results in significantly increased calcine waste volumes.

The objective of this program is to develop a sodium-bearing waste processing method which would separate the waste into a sodium-rich low-level fraction and a high-level fraction containing actinides, fission products, and hazardous components. The technology should minimize the volume of high-level waste requiring ultimate immobilization and disposal, as well as being environmentally acceptable and assuring the safety and health of the general public. Figure 4 illustrates the general flow scheme for all processing options.

Preliminary studies have identified several technologies as possibilities for processing sodium-bearing wastes, including direct solidification methods, neutralization, precipitation, solvent extraction, ion exchange, electrohydrolysis, and freeze crystallization. Technologies applicable to processing sodiumbearing wastes will be identified and defined with respect to operating conditions and equipment requirements. Although these tecinnologies are currently available, they may not be directiy applicable for use at ICPP due to incompatibility with facilities and processes. Therefore, possible modifications to make them applicable will be examined. Laboratory tests will be performed for selected processing methods to scope out the technical feasibility of the concepts. Components/subsystems for acceptable options will be identified, procured and tested on a pilot scale. A radioactive demonstration of the selected processing method will be performed. 


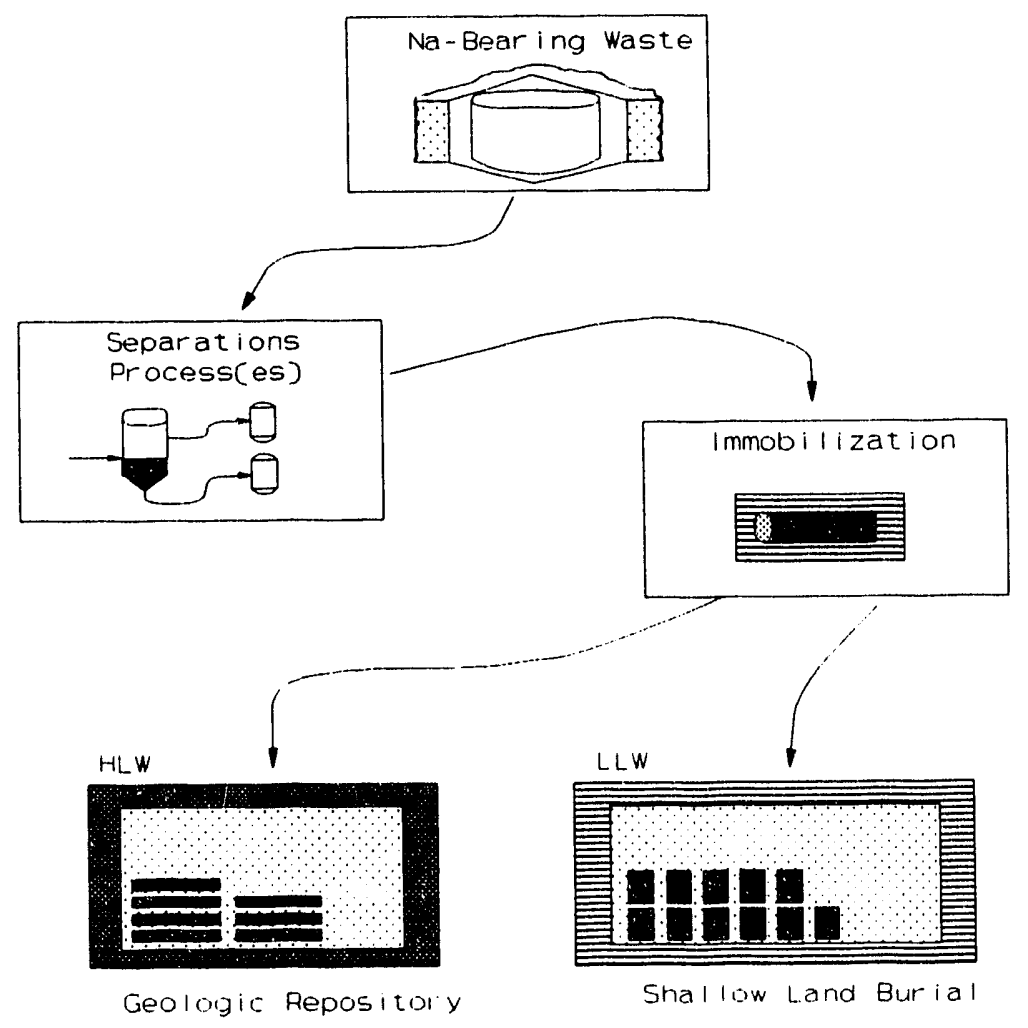

FIGURE 4

\section{GENERAL SODIUM-BEARING WASTE TREATMENT FLOW SCHEME}

Since a major portion of the sodium-bearing waste was generated as a result of decontamination activities, this program will also consider alternative decontamination methods. Some potential options, identified through preliminary studies, include abrasion, electropolishing, ultrasonics, carbon dioxide blasting, light ablation, and alternative chemicals. It is intended to develop as many of these as practical to maturity.

CALCINE IMMOBILIZATION TECHNOLOGIES 
TABLE IV

COMPOSITION OF ICPP CALCINE

Type of Calcine and Composition, wt\%

$\begin{array}{llll}\begin{array}{l}\text { Component } \\ \text { Fluorinel - }\end{array} & \text { Alumina } & \text { Zirconia } & \text { Blend } \\ \mathrm{Al}_{2} \mathrm{O}_{3} & 82-95 & 13-17 & 9 \\ \mathrm{Na}_{2} \mathrm{O} & 1-3 & -- & 4.8 \\ \mathrm{~K}_{2} \mathrm{O} & -- & -- & 1.2 \\ \mathrm{ZrO}_{2} & -- & 21-27 & 17-18 \\ \mathrm{CaF}_{2} & -- & 50-56 & 41-42 \\ \mathrm{CaO} & -- & 2-4 & 12 \\ \mathrm{SO}_{2} & --- & -- & 3 \\ \mathrm{~B}_{2} \mathrm{O}_{3} & 0.5-2 & 3-4 & 3.0-3.4 \\ \mathrm{CdO} & --- & --- & 6.7-7.0 \\ \mathrm{Misc} . & 0.5-1.5 & 0.5-1.5 & 0.5-1.5 \\ \text { Fission Products } & <1 & <1 & <1\end{array}$

and Actinides

a Contains additional nitrate at $10-15 \mathrm{wt} \%$

The objective of the Calcine Immobilization Program is to develop and demonstrate a process to immobilize ICPP HLW calcine in an acceptable form and minimum volume for final disposal. Areas of effort included in this task are (1) defining disposal criteria based on applicable regulations, (2) evaluating alternative technologies for feasibility and overall volumes. (3) developing waste form formulations for the feasible alternatives, (4) conducting nonradioactive and radioactive verification studies of various technologies, including grinding, degassing, densification, 
robotic areas, and waste form formulations, and (5) testing of subsystem components in an integrated pilot plant to provide operating parameters needed for full-scale design. The composition of ICPP calcine is given in Table IV.

Several technologies have been identified to date that could immobilize calcine; these include vitrification and glass-ceramic processing. Nonradioactive and radioactive laboratory tests have been carried out to develop glass waste forms for existing calcines. Some nonradioactive glass-ceramic forms with high waste loadings of 50 to $70 \mathrm{wt}$ percent have been prepared using simulated calcine and have shown leach rates similar to glass. Limited small-scale component and mock-up tests have been performed for selected unit operations of the glass-ceramic process, including calcine grinding, calcine transport, and vessel filling. Simplified, small-scale calcine retrieval mock-up tests have been run using calcium carbonate as a nonhazardous stimulant. The work, while not complete, provides confidence that acceptable processes can be developed in a reasonable period of time. A simplified schematic of the glass-ceramic process is given in Figure 5 .

Nonradioactive and radioactive tests will be run to characterize the glass-ceramic materials and to verify the acceptable range of compositions for the most promising formulations. The results of the tests will be used to develop waste acceptance preliminary specifications (WAPS) and to establish criteria for pilot scale tests. Non radioactive and radioactive tests will be run to establish feasibility and criteria for component tests.

Calcine retrieval component tests are required to verify new technologies in pneumatic and robotics areas. Glass-ceramic component tests are required in all of the unit operations in the process, including calcine-additive blending, grinding, transport, vessel filling, remote welding of vessel, densification of calcineadditive mixture to form a glass-ceramic, and packaging and decontamination of the waste form for disposal. The component testing will be carried out in ICPP pilot plants. The results of these tests will be used to select the process components and to design an integrated pilot plant for demonstration tests. 

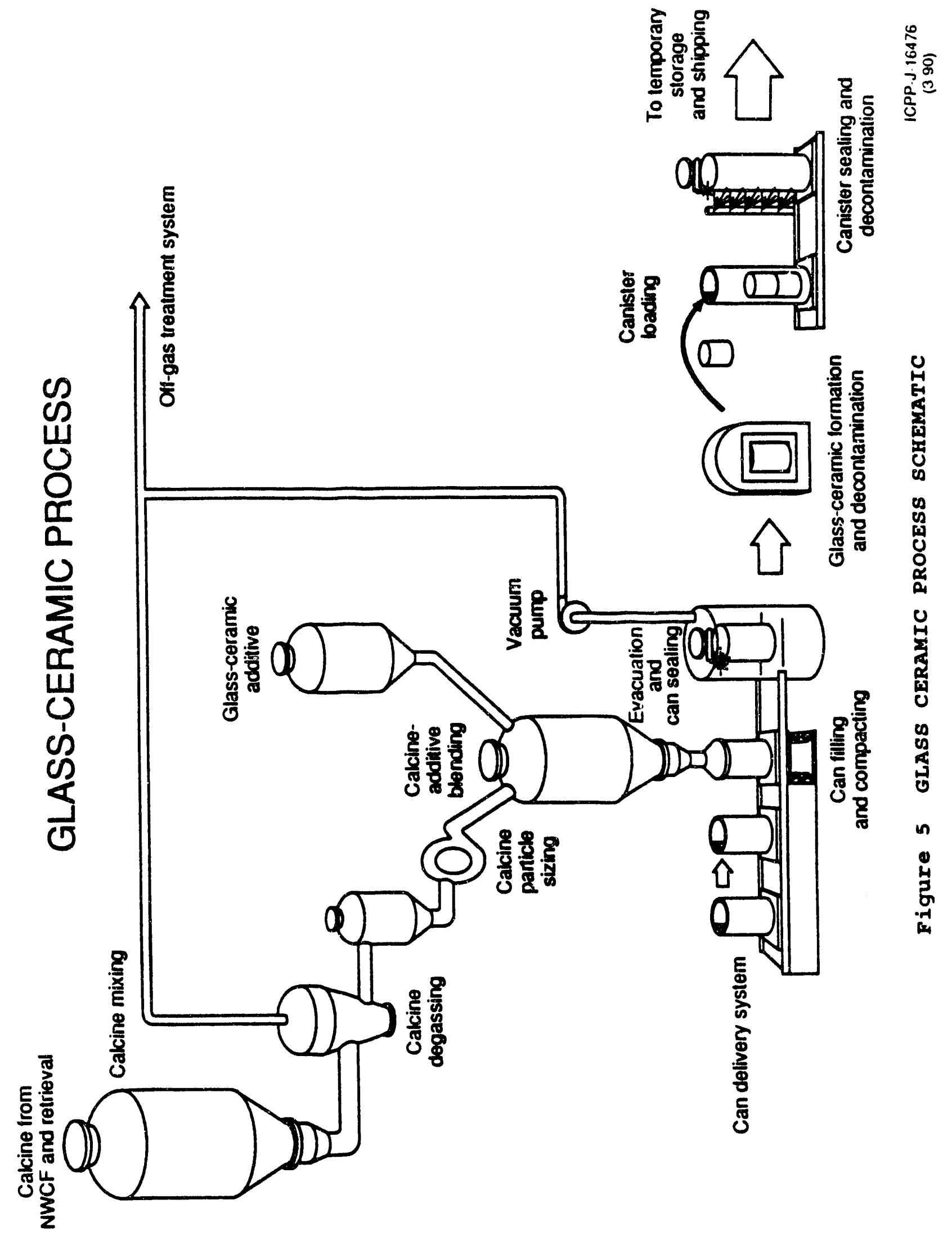

1 
The overall program schedule assuming glass-ceramic shows a record of decision for the full scale immobilization plant in the year 2003 and hot start-up of a production facility in 2014.

\section{METAL RECYCLE/WASTE MINIMIZATION}

Based on very preliminary information, DOE estimates that about 1.5 millions tons of radioactive scrap metal (RSM) is stored at various DOE facilities. There will be further amounts generated as DOE facilities are decontaminated and decommissioned. The current method of storing unsheltered piles of RSM on open ground may be restricted or discontinued in the future. The major options for future disposition of the RSM are beneficial reuse, engineered interim storage and LLW disposal.

The ICPP program addresses RSM management and disposition with emphasis on recycle and beneficial reuse: it includes support for coordination of RSM activities. Supporting program elements described in the ICPP plan include: (1) Source Compilations, (2) Regulations/Criteria, (3) Systems Analysis/Life Cycle Cost Estimates, (4) Decontamination, and (5) Industrial Interfaces/Technology Transfer. The Metal Recycle Program will also involve programs to demonstrate the restricted recycle of radioactive stainless steel (SS). Assessment of SS melting technologies and potential recycle of ICPP SS from the first phase of the Fuel Storage Reracking Project will be addressed.

\section{CONCLUSIONS}

1. The ICPP Spent Fuel and Waste Management Technology Development Plan was implemented to identify acceptable disposal options for radioactive wastes and irradiated spent fuel.

2. The ICPP Technology Development plan was developed jointly by WINCO and DOE.

3. A thorough systems analysis program has been initiated to consider repository performance and assure process development is conducted in a manner that assures final 
implementation is environmentally acceptable, ensures puviic and worker safety, and is cost effective.

4. A system for developing and using the technology acceptance criteria is implemented which assures all feasible options are considered, provides a check-list of information required for considering a given option, and provides the justification for studying the option.

5. The metal recycle/waste minimization program is in place to help coordinate and develop effective methods to recycle large quantities of contaminated metals from decommissioned processing plants. 

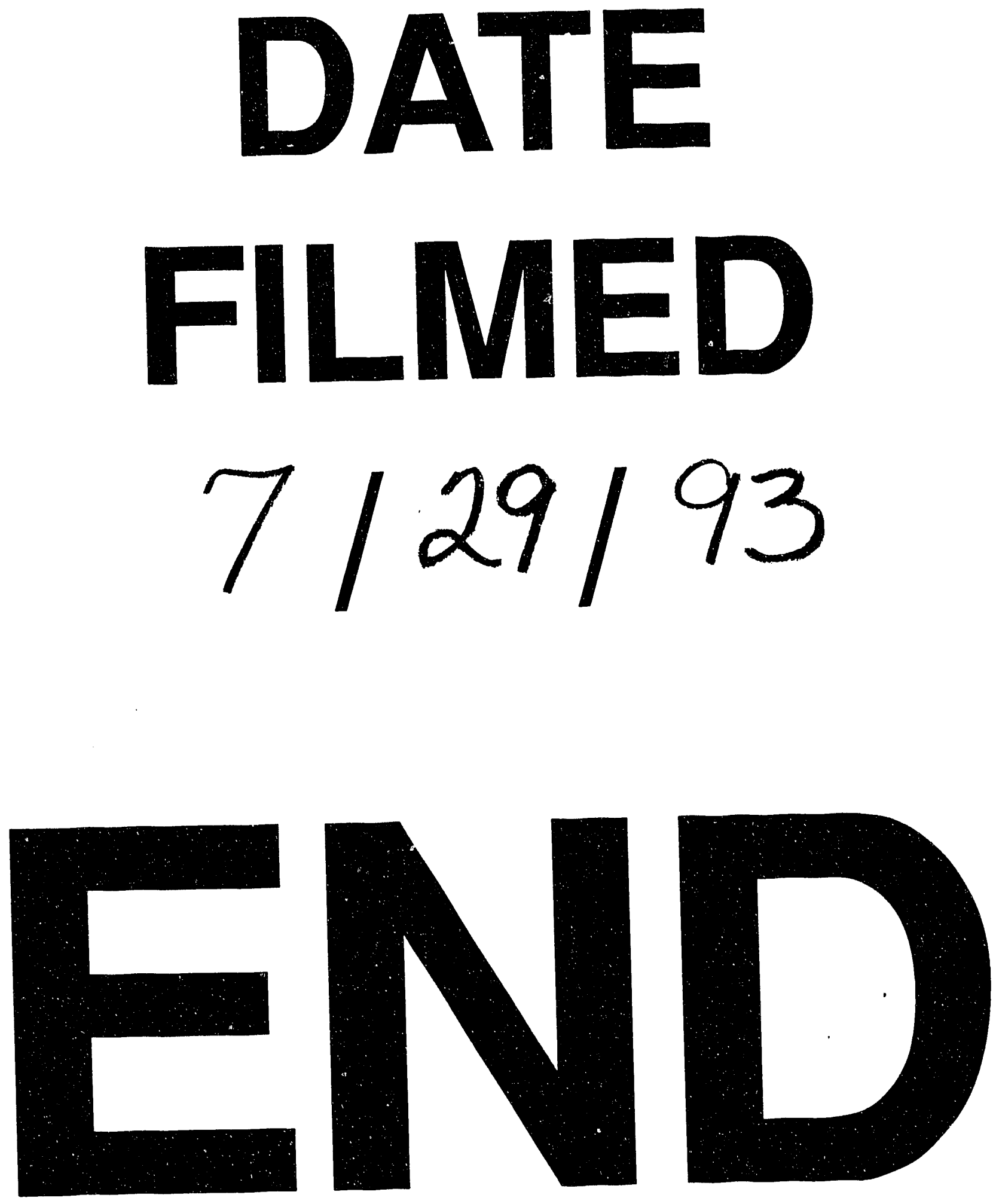
